\title{
Perancangan Sistem Terintegrasi pada Aplikasi Siklus Akuntansi dengan Evaluasi Technology Acceptance Model (TAM)
}

\author{
Dwi Ely Kurniawan ${ }^{a}$, Azis Saputra ${ }^{b}$, Purwono Prasetyawan $^{c}$ \\ ${ }^{a}$ Teknik Informatika, Politeknik Negeri Batam, dwialikhs@polibatam.ac.id \\ ${ }^{\mathrm{b}}$ Teknik Informatika, Politeknik Negeri Batam, azissaputra1989@gmail.com \\ 'Teknik Elektro, Fakultas Teknik dan Ilmu Komputer, Universitas Teknokrat, purwono.prasetyawan@teknokrat.ac.id
}

\begin{abstract}
The accounting cycle is used to see the picture of a company's circumstances in decision-making, whether the company gains or loses. The development of information technology at this time developed so rapidly, so the company is required to continue to innovate to improve company performance. Factors that cause information delays, lack of organized information processing and unintegrated data cause the company difficulties in controlling financial flows. This research designs an application of financial accounting cycle using Enterprise Resource Planning (ERP) and Technology Acceptance Model (TAM) approach. ERP is known as an integrated system between business processes with each other while the TAM model to see the factors of user acceptance of business process changes using the application. Based on the results of the design of applications that have been developed with several main criteria obtained the benefit criteria with $75 \%$ percentage, convenience criteria with percentage $76.67 \%$, usability criteria with $77.5 \%$ percentage, graphic design criteria with percentage $80 \%$, compatibility criterion with percentage $60 \%$ and functionality criteria with a percentage of $72.5 \%$, so it can be concluded that the application is useful, easy to use, but it is easier in controlling and making decisions based on these parameters
\end{abstract}

Keywords: accounting cycle, ERP, TAM

\begin{abstract}
Abstrak
Siklus akuntansi digunakan untuk melihat gambaran keadaan suatu perusahaan dalam pengambilan keputusan, apakah perusahaan tersebut memperoleh keuntungan atau mengalami kerugian. Perkembangan teknologi informasi saat ini berkembang begitu pesat, sehingga perusahaan dituntut untuk terus berinovasi untuk meningkatkan performance perusahaan. Faktor y ang meny ebabkan keterlambatan informasi, kurang terorganisasiny a pengolahan informasi dan data tidak terintegrasi menyebabkan perusahaan kesulitan dalam mengendalikan arus keuangan. Penelitian ini merancang suatu aplikasi siklus akuntansi keuangan menggunakan pendekatan Enterprise Resource Planning (ERP) dan Technology Accepteance Model (TAM). ERP dikenal dengan sistem terintegrasiny a antar proses bisnis satu dengan yang lain sedangkan model TAM untuk melihat faktor penerimaaan pengguna terhadap perubahan proses bisnis menggunakan aplikasi. Berdasarkan hasil perancangan aplikasi yang telah dikembangkan dengan beberapa kriteria utama diperoleh kriteria kemanfaatan dengan persentase $75 \%$, kriteria kemudahan dengan persentase $76,67 \%$, kriteria usability dengan persentase 77,5\%, kriteria graphic design dengan persentase $80 \%$, kriteria compability dengan persentase $60 \%$ dan kriteria functionality dengan persentase $72,5 \%$, sehingga dap at ditarik kesimpulan bahwa aplikasi ini bermanfaat, mudah digunakan, selain itu memudahkan dalam pengendalian dan pengambilan keputusan berdasarkan parameter tersebut.
\end{abstract}

Kata kunci: siklus akuntansi, ERP, TAM

(C) 2018 Jurnal RESTI

\section{Pendahuluan}

Akuntansi merupakan proses pencatatan, penggolongan dan penyajian informasi kegiatan ekonomi ke dalam Perkembangan teknologi saat ini memicu perusahaan bentuk laporan keuangan yang menjelaskan kondisi untuk menggali potensi yang dimiliki perusahaan untuk perusahaan kepada pihak-pihak yang membutuhkan dapat lebih meningkatkan performance perusahaan. laporan, terutama untuk pemilik usaha itu sendiri. Bagaimana perusahaan dituntut untuk menemukan Laporan tersebut digunakan dalam mengelola strategi, dimulai dengan menentukan tujuan dan arah bisnis dalam jangka panjang. Untuk membangun strategi

\begin{tabular}{l|l|l} 
Diterima Redaksi : 02-03-2018 & Selesai Revisi : 14-04-2018 & Diterbitkan Online : 16-04-2018
\end{tabular} 
yang tepat bagisebuah perusahaan, dibutuhkan data dan yang ditujukan kepada departemen penjualan dalam informasi keuangan yang mencukupi. Karena itu, peran bentuk surat atau telepon langsung oleh pelanggan akuntansi dalam proses bisnis pembangunan strategi kepada bagian penjualan dan kemudian akan membuat perusahaan sangat vital. Sedangkan sistem akuntansi sales order untuk didistribusikan ke departemen lain merupakan proses dari ekonomi yang berguna dalam yang berkaitan dengan masalah penjualan. Fungsi dari pengambilan keputusan [1]. Hampir dari $80 \%$ bisnis departemen kredit meliputi penyetujuan atau otorisasi tutup atau tidak berkembang karena tidak didukung atas transaksi yang mencakup verifikasi atas kelayakan manajemen administrasi yang baik. Berberapa hasil kredit dapat diberikan kepada pelanggan. Selain itu, penelitian masih banyak bidang usaha yang pencatatan departemen kredit juga berperan dalam menyetujui akuntansinya masih tradisional, sehingga masalah- adanya retur dan potongan penjualan serta adanya masalah yang ditemukan adalah duplikasi penomoran, penyesuaian atas rekening pelanggan, menilai dan kesalahan dalam pencatatan, kelalaian dan kurangnya menyetujui neraca saldo umur piutang dalam penentuan pengendalian internal.

Dalam kenyataan sehari-hari masih banyak bidang usaha yang belum menggunakan aplikasi pencatatan keuangan yang terintegrasi dengan baik. Beberapa bidang usaha masih dilakukan secara manual. Seperti pada PT.XYZ yang masih menggunakan manual paper dan perangkat spreadsheet. Kesulitan dalam melakukan pencarian data, mengatasi file yang tiba-tiba error, proses loading cukup lama dan kurang banyak pengetahuan tentang rumus spreadsheet. Selain itu Salinan surat penjualan barang yang berasal dari karena data tidak terintegrasi, menyebabkan kesulitan departemen penjualan atas adanya pesanan penjualan dalammengendalikan arus keuangan perusahaan [2] [3]. yang dikelola kemudian oleh bagian gudang Hal ini tentu akan mengganggu jalannya suatu usaha mengisyaratkan untuk mempersiapkan barang yang atau bisnis.

Beberapa penelitian sejenis diantaranya pengembangan sistem HRM terintegrasi [4], penerapan ERP pada sistem informasi pembelian, persedian dan penjualan barang [5], penerapan ERP menggunakan modul [6], memberikan kemudahan dalam pengendalian sistem dan pengambilan keputusan untuk keberlanjutan perusahaan. Selain itu analis is dampak penerapan sistem sisa kredit dari pelanggan. Salinan dari persetujuan kredit atas penjualan akan dikelola dan disimpan dalam file pesanan pelanggan sampai berakhirnya transaksi. Faktur, memo kredit dan penyesuaian faktur lainnya yang diterima pada saat persetujuan kredit oleh departemen penagihan sebagai tanda terima dari dokumen pengiriman atas pengeluaran barang akan dikelola ke piutang dagang untuk diposting ke rekening pelanggan.

diinginkan oleh pelanggan sesuai dengan pesanan dan mengeluarkan barang yang dimaksud. Setelah petugas menulis inisial pada salinan surat pengeluaran barang yang mengindikasikan bahwa pesanan sudah lengkap dan benar, satu salinan surat pengeluaran barang akan dikirimkan ke departemen pengiriman dan salinan lainnya akan disimpan di gudang sebagai catatan transaksi.

ERP terhadap kinerja pengguna [7], terhadap Pengiriman barang akan dilakukan oleh departemen manajemen produksi [8], dapat berdampak positif pengiriman setelah departemen pengiriman menerima terhadap kinerja pengguna, mempermudah dan surat pengiriman barang dari departemen persediaan mempercepat dalam pengelolaan produksi, persediaan (bagian gudang). Dokumentasi atas adanya pengiriman dan distribusi barang serta membantu manajemen dalam barang akan disiapkan oleh departemen pengiriman proses pengambilan keputusan. Penelitian ini akan sebuah bill of lading yaitu pertukaran dokumentasi mencoba menerapkan pendekatan ERP terintegrasi di antara pengirim dan pengangkut.

masing-masing perusahaan cabang pada pengembangan aplikasi siklus akuntansi perushaan XYZ serta menerapkan model TAM dalam mengevaluasi penerimaan pengguna terhadap sistem yang baru yang akan diimplementasikan.

\section{Landasan Teori}

\subsection{Siklus Akuntansi Keuangan}

Setiap perusahaan pasti memiliki proses bisnis, secara umum proses bisnis itu meliputi proses penjualan, proses kredit, proses penagihan, proses pengeluaran barang dari gudang, proses pengiriman barang, proses update stok, proses piutang dagang, proses pencatatan buku besar.

Dalam hal pemutakhiran data persediaan barang dilakukan berdasarkan atas dokumen pengeluaran barang dari departemen pengiriman yang akan dilakukan oleh bagian akuntansi yang akan memperbaharui catatan akun buku besar pembantu persediaan, dan setelah proses pembukuan selesai dilakukan dokumen pengeluaran barang akan disimpan. Bagian yang berperan atas pencatatan piutang dagang oleh pelanggan dilakukan oleh departemen akuntansi bagian piutang dagang dengan cara membukukan salinan buku besar pesanan penjualan ke buku besar pembantu piutang dagang dan setelah proses pembukuan selesai dilakukan staff piutang dagang akan menyimpan salinan buku besar yang akan merangkum setiap saldo akun menjadi satu dan mengirimkannya ke Proses penjualan diawali dari adanya pesanan dari buku besar umum. Pengendalian persediaan dan ikhtisar pelanggan yang menyatakan jenis dan kuantitas barang setiap akun yang berasal dari piutang dagang akan

Jurnal RESTI (Rekayasa Sistem dan Teknologi Informasi) Vol. 2 No. 1 (2018) 315 - 321 
terlaksana pada saat penutupan periode pemrosesan setelah departemen buku besar umum telah menerima voucher journal dari departemen penagihan.

\subsection{Enterprise Resource Planning (ERP)}

Sistem informasi perusahaan saat ini dikenal dengan sistem yang terintegrasi, dimana perusahaan dalam aktifitas bisnisnya mampu mengoperasikan bisnis dan mengelola data secara otamatisasi, sehingga data yang diperoleh benar-benar akurat dan tepat. Apalagi bila data pada perusahaan tersebut terdis tribusi dan terintegrasi ke pengguna dengan baik, maka aktifitas bisnis mampu dikendalikan dan menunjang keputusan pada level puncak perusahaan.

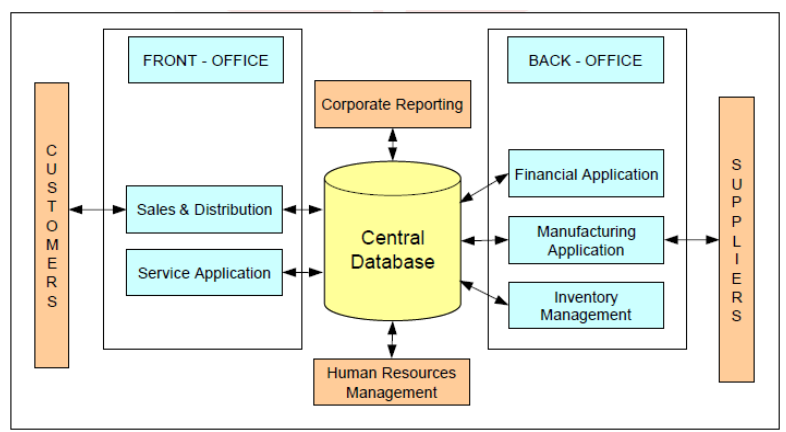

Gambar 1. Enterprise Resource Planning (ERP)

Gambar 1 menjelaskan bahwa ERP merupakan perangkat lunak manajemen proses bisnis yang memungkinkan sebuah organisasi menggunakan sistem aplikasi terintegrasi untuk mengelola bisnis dan mengotomatisasi banyak fungsi front office dan back office yang berkaitan dengan teknologi, layanan dan sumber daya manusia. ERP mengintegrasikan semua aktivitas bisnis dan proses perusahaan dalamsatu sistem perangkat lunak. Penerapan sistem terintegrasi (ERP) pada aplikasi siklus akuntansi memungkinkan untuk mengotomatiasi data dari serangkaian proses bisnis dari siklus akuntansi yang meliputi; analisis transaksi, pencatatan jurnal, posting ke buku besar, pembuatan neraca saldo, posting jurnal, dan pembuatan laporan keuangan.

\subsection{Technology Acceptance Model (TAM)}

TAM menjelaskan perilaku pengguna komputer. Model TAM mengidentifikasi penerimaan pengguna dan memberikan kemungkinan langkah yang tepat. Tujuan utama TAM sesungguhnya adalah untuk memberikan dasar langkah dari dampak suatu faktor eksternal pada kepercayaan internal (internal beliefs), sikap (attitude) dan niat (intention). Faktor-faktor yang mempengaruhi secara kognitif dan afektif pada penerimaan komputer.

Gambar 2 menjelaskan bahwa Technology Acceptance Model (TAM) terdiri dua faktor yaitu:
1) Persepsi kemudahan (perceived ease of use) yakni sejauh mana seorang percaya bahwa menggunakan suatu teknologi akan memudahkan pekerjaan.

2) Persepsi kegunaan (perceived usefulness) yakni, sejauh mana seorang percaya bahwa menggunakan suatu teknologi akan meningkatkan kinerjanya.

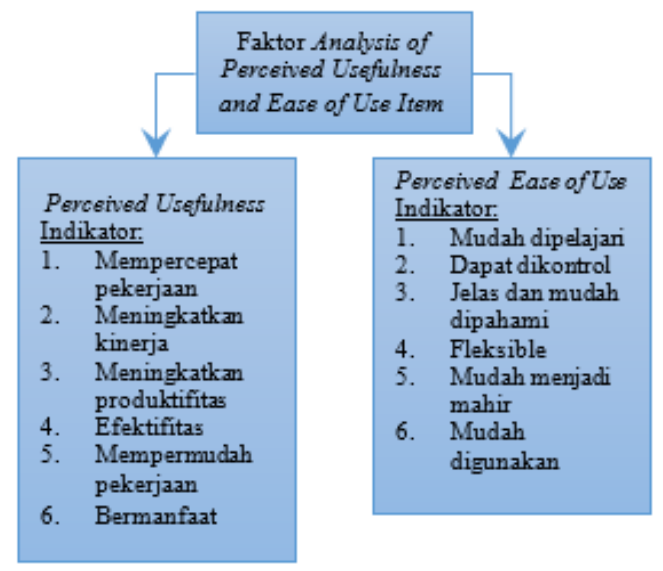

Gambar 2. Faktor T AM

\section{Metodologi Penelitian}

Metodologi penelitian ini meliputi survei sistem yang sedang berjalan, analisis kebutuhan sistem, perancangan, implementasi dan evaluasi penggunaan sistem yang baru. Secara detail ilustrasi penelitian digambarkan pada Gambar 3.

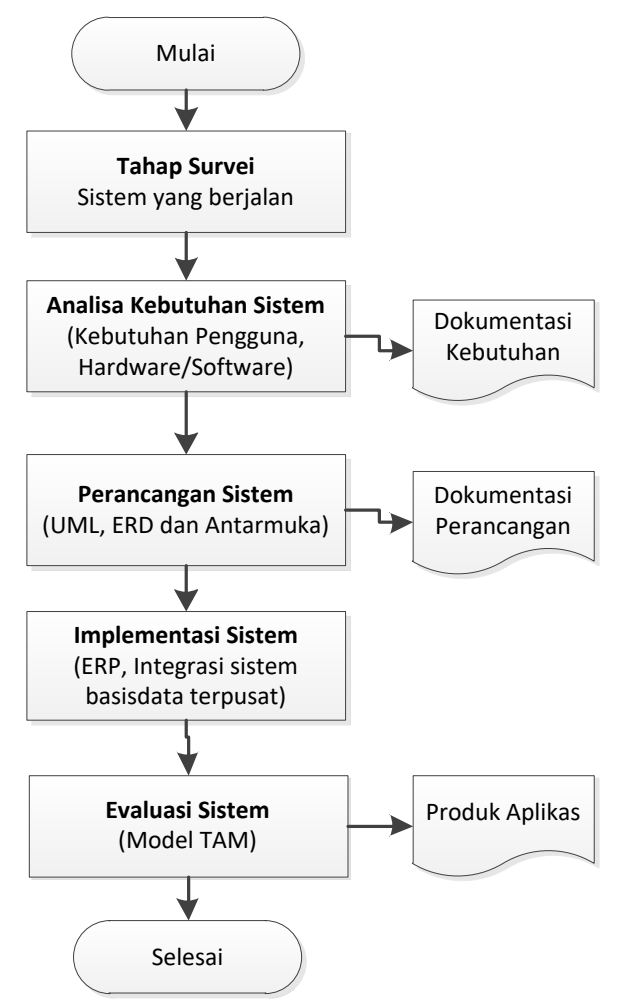

Gambar 3. Metodologi Penelitian Pengembangan Aplikasi 
Tahap survei dilakukan dengan mengamati dan 3) mendapatkan secara rinci sistem yang berjalan saat ini. Tahap analisa kebutuhan sistem dilakukan dengan memberikan kuesioner pengguna, mengamati sarana dan prasarana yang ada untuk menghasilkan dokumen kebutuhan sistem secara keseluruhan. Tahap perancangan sistem membuat use case, skenario, squence diagram, class diagram, ERD dan tampilan antarmuka untuk menghasilkan dokumen perancangan sistem. Tahap implementasi sistem pada basisdata terpusat dengan melakukan pendekatan ERP. Evaluasi sistem memberikan kuesioner umpan balik terhadap sistem yang baru dikembangkan dengan pendekatan 4) model TAM.

Tahap survei dengan mengamati sistem yang sedang berjalan diperoleh siklus akuntansi dalam perusahaan XYZ pada Gambar 4.
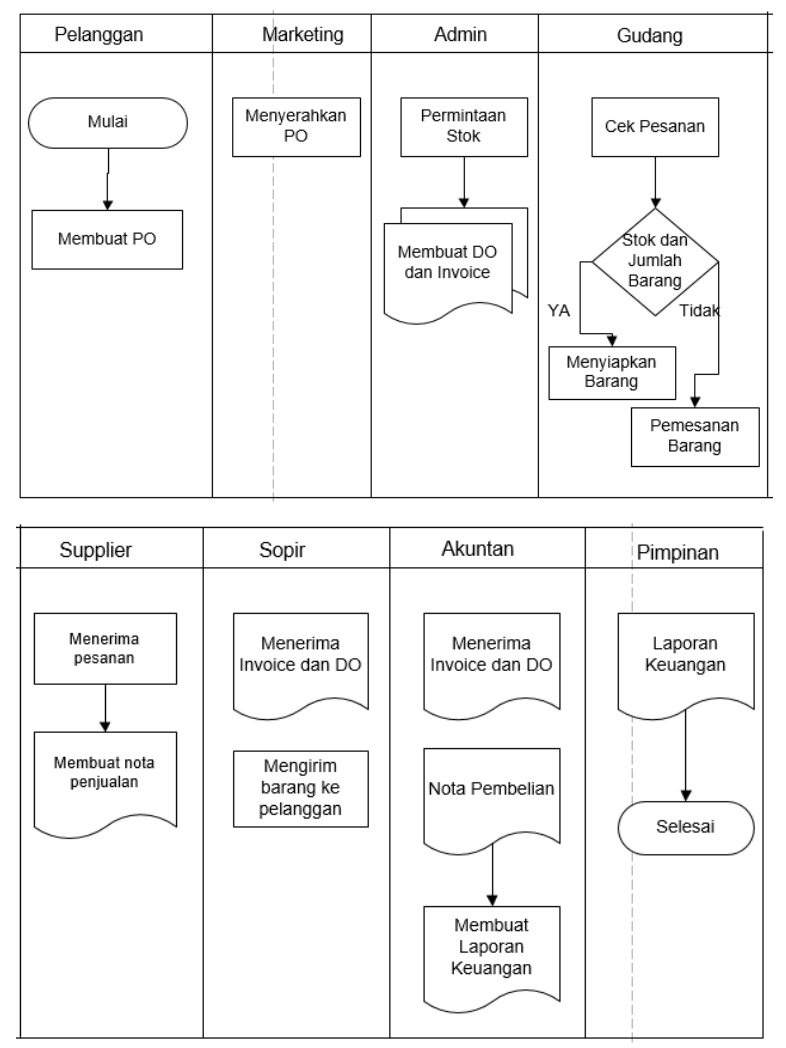

Gambar 4. Sistem yang berjalan

Siklus akuntansi saat ini yang berjalan pada perusahaan XYZ tersebut secara rinci dijelaskan sebagai berikut.

1) Proses dimulai dari pelanggan membuat purchase order kepada bagian marketing. Pelanggan disini merupakan orang/perusahaan yang ingin membeli produk atau jasa dari perusahaan.

2) Bagian marketing menyerahkan purchase order tersebut kepada admin. Marketing merupakan karyawan yang bekerja di bidang pemasaran produk dan jasa dari perusahaan.
Admin melakukan permintaan stok kepada staff gudang, jika stok tersedia maka admin akan membuat surat delivery order dan invoice. Admin adalah karyawan yang bertugas menginput data penjualan dan membuat laporan penjualan. Surat delivery order merupakan surat perintah untuk penyerahan barang kepada pembawa surat, yang nantinya diserahkan kepada pelanggan. Invoice merupakan detail perhitungan penjualan yang diberikan oleh bagian marketing kepada pelanggan, biasanya berisi rincian nama barang, harga, berat, jumlah dan total harga yang harus dibayarkan.

Staff gudang menyiapkan barang sesuai jumlah permintaan jika stok tersedia. Jika stok tidak tersedia maka staff gudang akan melakukan permintaan barang atau order kepada supplier. Staff gudang merupakan orang yang bertugas mengontrol stok di gudang, menyiapkan barang pesanan pelanggan.

5) Supplier akan memberikan nota penjualan. Supplier adalah seseorang/perusahaan yang menjalankan usaha menyalurkan suatu barang/produk tertentu dalam jangka waktu tertentu.

6) Setelah semua sudah siap maka pengirim (driver) akan menerima delivery order dan invoice untuk mengirimkan barang kepada pelanggan.

7) Setelah barang terkirim ke pelanggan sopir menyerahkan file delivery order dan invoice kepada akuntan. Akuntan juga akan menerima nota pembelian jika ada pembelian atau pengeluaran kas.

8) Akuntan mengumpulkan semua data pembelian dan penjualan untuk membuat laporan keuangan. Akuntan merupakan orang yang terampil dalam praktek akuntansi atau yang bertanggung jawab atas rekening publik atau swasta. Selain itu juga melakukan fungsi akuntansi seperti audit, analis is laporan keuangan perusahaan.

9) Setelah selesai membuat laporan keuangan akuntan akan menyerahkan kepada pimpinan. Pimpinan merupakan pemegang kuasa pertama dari suatu perusahaan (pemilik atau manager).

10) Pimpinan akan mengetahui laba rugi perusahaan dan laporan keuangan lainnya. Sehingga seorang pemimpin dapat mengambil langkah selanjutnya untuk perkembangan perusahaannya.

Gambar 5, Tahap perancangan menggunakan bahasa UML berikut use case dari sistem yang dikembangkan. Gambar 6 Use case diagram terdapat tiga aktor diantaranya Manager, Administrator, Accounting. Interaksi saat pertama kali adalah pengguna melakukan login untuk kelola terhadap aktifitas bisnis. Aktifitas atau interaksi pengguna tersebut diantaranya kelola pengguna untuk menambah, hapus dan ubah serta hak akses pengguna (khusus administrator). Kelola rekening untuk membuat kode rekening baru yang akan digunakan pada jurnal umum nantinya. Kelola saldo awal untuk menambah saldo awal tahun lalu pada 
masing-masing kode rekening. Saldo awal ini dijumlahkan pada laporan buku besar, neraca, dan laba rugi. Kelola jurnal umum untuk menambah data jurnal baik pengeluaran, pendapatan maupun hutang dan piutang.

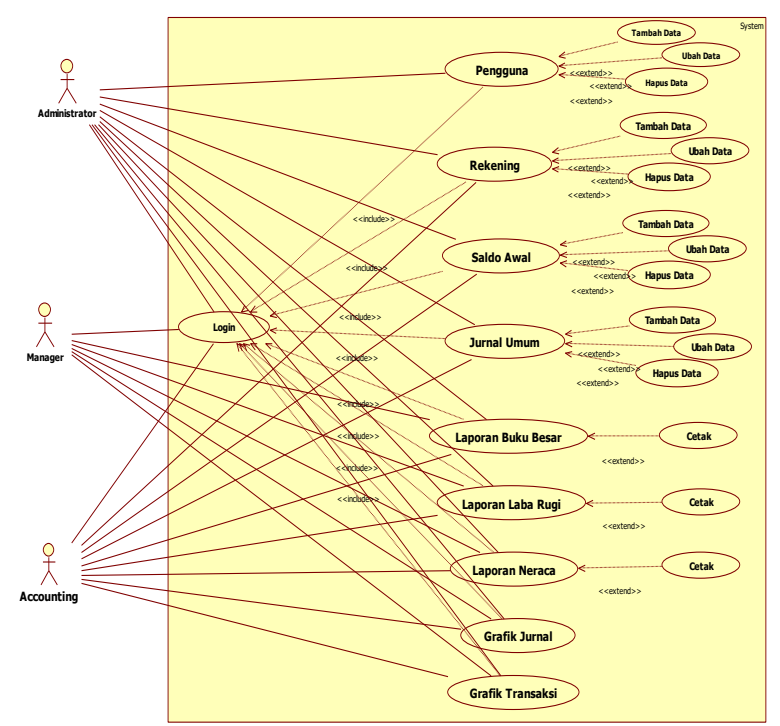

Gambar 5. Use case diagram

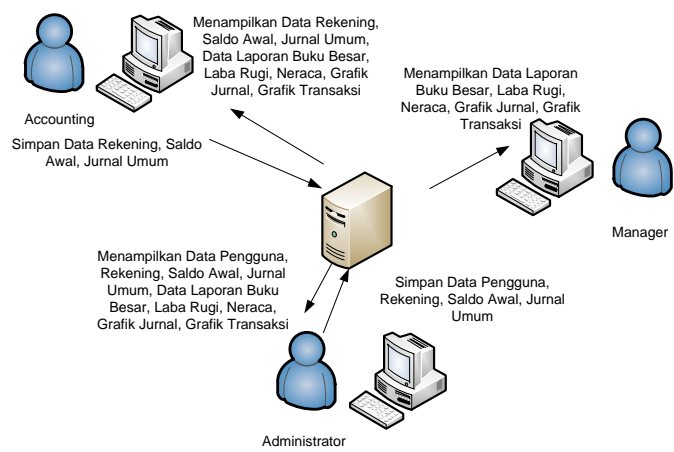

Gambar 6. Ilustrasi Sistem

Laporan buku besar untuk mencatat semua transaksi pada jurnal umum berdasarkan masing-masing kode rekening tiap tahun. Laporan laba-rugi untuk menampilkan jumlah keuntungan atau kerugian perusahaan. Laporan neraca untuk menjelaskan posisi keuangan dengan melaporkan aktiva, kewajiban dan ekuitas pemegang saham perusahaan pada waktu tertentu. Grafik jurnal untuk menampilkan grafik jurnal atau debit dan kredit secara keseluruhan selama satu tahun atau periode tertentu. Grafik transaksi untuk melihat jumlah transaksi dari masing-masing rekening, sehingga dapat mengetahui rekening apa saja yang sering digunakan dan paling banyak melakukan transaksi.

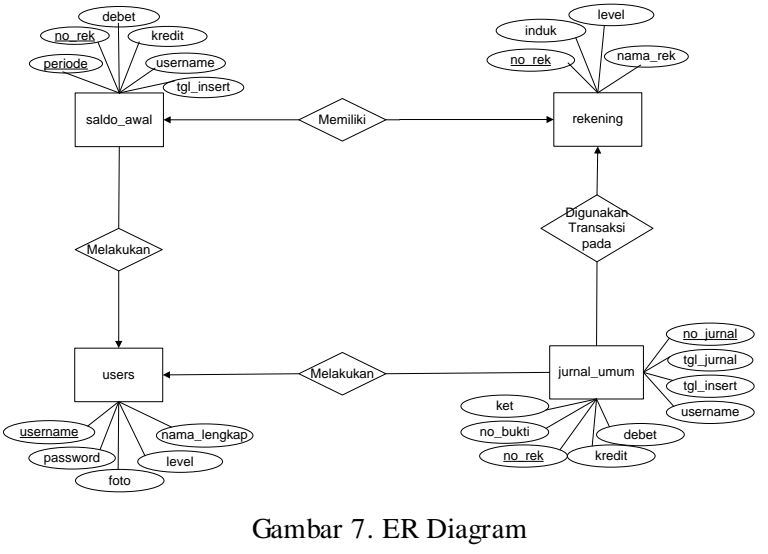

Gambar 7 perancangan basis data digambarkan dengan diagram ERD melibatkan 4 entitas diantaranya saldo awal, rekening, pengguna dan jurnal umum.

\section{Hasil dan Pembahasan}

Setelah melakukan analisa dan perancangan sistem selanjutnya mengimplementasikan hasil aplikasi baru yang telah dikembangkan. Gambar 8 merupakan tampilan halaman utama untuk mengakses aplikasi akuntansi keuangan berbasis web.

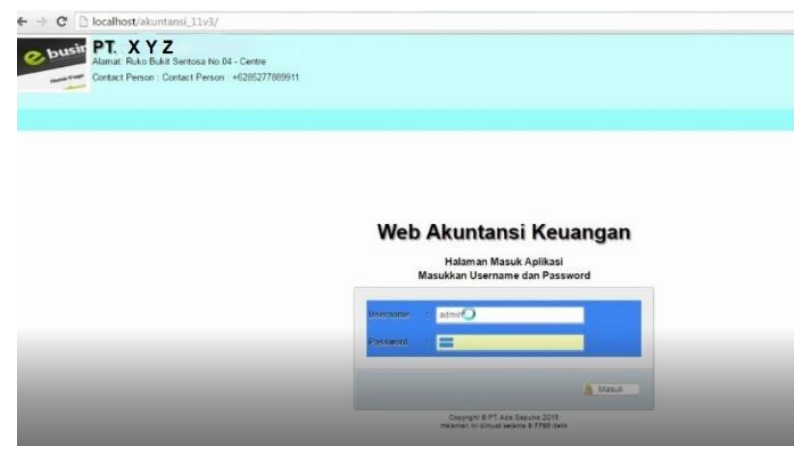

Gambar 8. Halaman Utama

Pengguna yang terlibat administrator, manager dan akunting akses ke dashboard aplikasi menggunakan user dan password sesuai dengan level user.

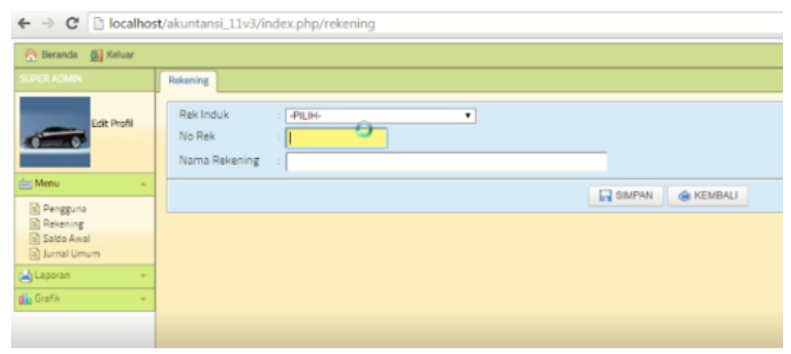

Gambar 9. Halaman Dashboard

Gambar 9 halaman dashboard, pengguna dapat memilih menu yang akan digunakan seperti menu Pengguna, Rekening, Jurnal Umum, Saldo Awal, Laporan Buku Besar, Laporan Laba Rugi, Laporan Neraca, Grafik Jurnal, dan Grafik Transaksi. 


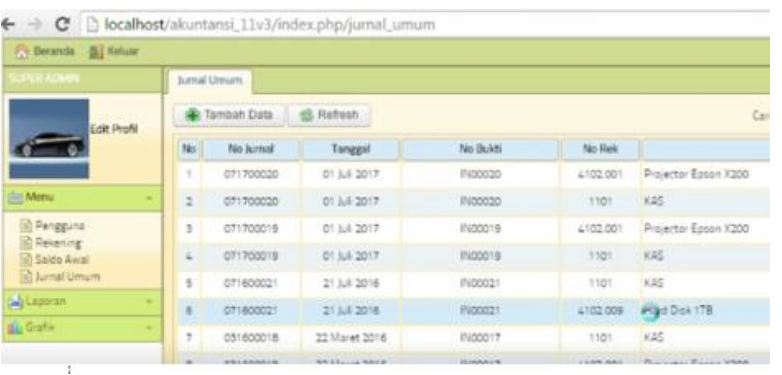

Gambar 10. Halaman Jurnal Umum

Gambar 10 halaman jurnal untuk mengakses jurnal umum untuk menambah data jurnal baik pengeluaran, pendapatan maupun hutang dan piutang.

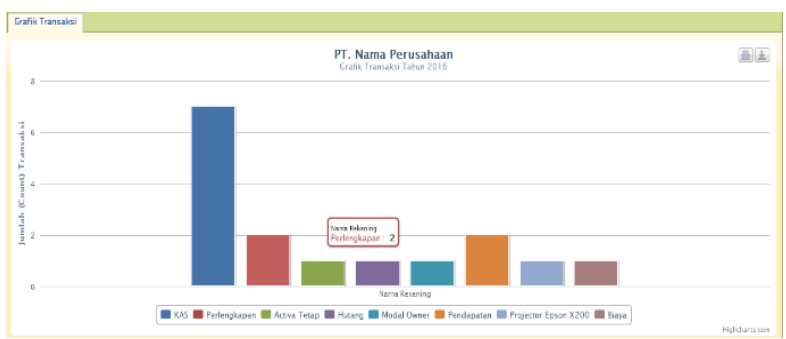

Gambar 11. Halaman Grafik Transaksi

Gambar 11 halaman grafik, pengguna dapat melihat jumlah transaksi dari masing-masing rekening sehingga dapat membantu manager dalam mengendalikan aktifitas bisnis dan mengambil keputusan. Selanjutnya melakukan evaluasi model TAM, ditunjukkan pada Gambar 12 merupakan contoh dari lembar keusioner evaluasi yang dilakukan.

Evaluasi pengujian menggunakan kuesioner yang diberikan kepada pengguna aplikasi dan lingkungan yang terlibat dalam proses bisnis pada siklus akuntansi di masing-masing perusahaan cabang, untuk melihat tingkat penerimaan pengguna terhadap teknologi baru yang digunakan tersebut. Parameter yang digunakan dalam kuesioner ini diantaranya; kemanfaatan, kemudahan, usability, desain, kompabilitas dan fungsional. Kemanfaatan berkaitan dengan peningkatan produktifitas, efektifitas dan efisiensi serta kemudahan dalam bekerja. Kemudahan yang dimaksud berkaitan dengan mempelajari aplikasi. Usabilitas berkaitan dengan struktur, desain, text dalam penggunaan menu dan tampilan.

Pengujian dilakukan terhadap 30 responden dari masing-masing perusahaan cabang dengan latar belakang pendidikan, jabatan dan usia. Hasilnya diperoleh dari enam parameter tersebut disajikan dalam bentuk grafik pada Gambar 13.

Hasil yang diperoleh dari grafik tingkat penerimaan pengguna bahwa kriteria kemanfaatan (perceived usefulness) persentase sebesar $75 \%$, kriteria kemudahan (perceived ease of use) persentase sebesar 76,67\%. Selain itu kriteria lain usability persentase sebesar $77,5 \%$, kriteria desain persentase sebesar $80 \%$, kriteria kompabilitas persentase sebesar $60 \%$ dan kriteria fungsional persentase sebesar 72,5\%. Sehingga dari grafik tersebut dapat ditarik kesimpulan bahwa aplikasi ini bermanfaat, mudah digunakan, tampilan grafik juga baik, semua menu dapat berjalan dengan baik dan aplikasi ini dapat berjalan di berbagai macam browser. Pada pertanyaan dukungan browser dan fungsional telah berjalan dengan baik. Responden banyak yang menjawab sangat baik artinya setuju untuk menggunakan teknologi atau sistem yang baru. KUESIONER EVALUASI

\begin{tabular}{|c|c|c|c|c|c|c|c|}
\hline \multicolumn{2}{|c|}{ Nama } & : & & & & & \\
\hline \multicolumn{2}{|c|}{ Jabatan } & : & & & & & \\
\hline \multicolumn{2}{|l|}{ Usia } & $:$ & & & & & \\
\hline \multicolumn{2}{|c|}{ Pendidikan } & : & & & & & \\
\hline No & \multicolumn{3}{|c|}{ Kriteria Penilaian } & SB & B & CB & KB \\
\hline \multirow{3}{*}{1} & \multirow{3}{*}{ Kemanfaatan } & $\mathrm{a}$ & $\begin{array}{l}\text { Apakah dapat memudahkan } \\
\text { pekerjaan anda }\end{array}$ & & & & \\
\hline & & b & Apakah meningkatkan produktivitas & & & & \\
\hline & & c & Apakah lebih efektif dan efisien & & & & \\
\hline \multirow{3}{*}{2} & \multirow{3}{*}{$\begin{array}{l}\text { Kemudahan } \\
\text { Penggunaan }\end{array}$} & a & Apakah aplikasi mudah digunakan & & & & \\
\hline & & b & $\begin{array}{l}\text { Apakah mudah dimengerti dan } \\
\text { dipahami }\end{array}$ & & & & \\
\hline & & c & $\begin{array}{l}\text { Apakah anda cepat mahir dalam } \\
\text { menggunakannya }\end{array}$ & & & & \\
\hline \multirow{4}{*}{3} & \multirow{4}{*}{ Usability } & a & Struktur menu mudah dipahami & & & & \\
\hline & & b & Mudah di ingat & & & & \\
\hline & & c & Efektif dan Efisien & & & & \\
\hline & & d & Desain dan tata letak yang baik & & & & \\
\hline \multirow{3}{*}{4} & \multirow{3}{*}{$\begin{array}{l}\text { Pengujian } \\
\text { Graphic Design }\end{array}$} & $\mathrm{a}$ & $\begin{array}{l}\text { Apakah komposisi warnanya baik } \\
\text { dan konsisten }\end{array}$ & & & & \\
\hline & & b & Apakah text mudah di baca & & & & \\
\hline & & c & $\begin{array}{l}\text { Apakah penggunaan animasi sudah } \\
\text { tepat }\end{array}$ & & & & \\
\hline 5 & $\begin{array}{l}\text { Pengujian } \\
\text { Compatibility }\end{array}$ & a & $\begin{array}{l}\text { Dukungan browser (Mozila Firefox, } \\
\text { Google Chrome, IE, opera) }\end{array}$ & & & & \\
\hline \multirow{2}{*}{6} & \multirow{2}{*}{$\begin{array}{l}\text { Pengujian } \\
\text { Functionality }\end{array}$} & a & $\begin{array}{l}\text { Masing-masing menu berfungsi } \\
\text { dengan baik }\end{array}$ & & & & \\
\hline & & b & $\begin{array}{l}\text { Tombol button berfungsi dengan } \\
\text { baik }\end{array}$ & & & & \\
\hline
\end{tabular}

Gambar 12. Kuesioner Evaluasi

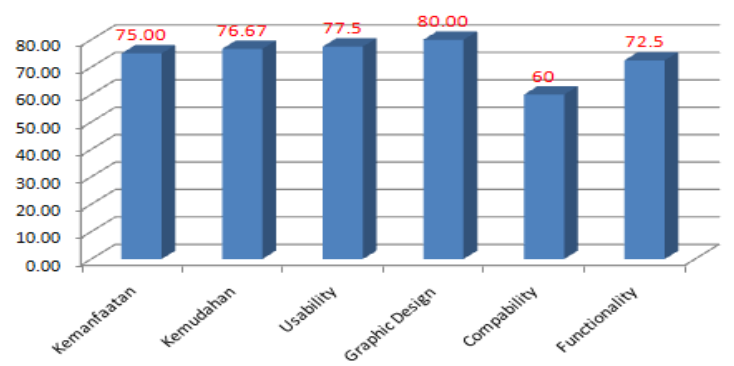

Gambar 13. Grafik Tingkat Penerimaan Pengguna

\section{Kesimpulan}

Berdasarkan hasil implementasi dan pembahasan maka dapat disimpulkan sebagai berikut.

1) Sistem terintegrasi pada aplikasi siklus akuntansi telah dikembangkan sehingga memudahkan pihak manager atau pemegang perusahaan dapat mengendalikan bisnis dan membuat keputusan berdasarkan grafik perkembangan aktifitas bisnis yang sedang berjalan. 
2) Evaluasi pengujian penerimaan pengguna terhadap teknologi atau sistem baru yang telah dikembangkan berdasarkan parameter kemanfaatan (perceived usefulness) sebesar $75 \%$, sutuju sudah memberikan manfaat kepada pengguna.

3) Parameter kemudahan (perceived ease of use) sebesar $76,67 \%$, setuju memberikan kemudahan kepada pengguna.

4) Selain itu faktor lain; usability $77,5 \%$, desain $80 \%$, kompatibilas $60 \%$ dan fungsional $72,5 \%$. Artinya dari evaluasi pengguna menerima baik terhadap perubahan sistem yang baru.

\section{Ucapan Terima Kasih}

Penulis mengucapkan terimakasih kepada Ricca Vibriyanthy, dkk dalam membantu pengambilan dan pengolahan data penelitian.

\section{Daftar Rujukan}

[1] Kurniawan, D.E., Pujiyono, 2016. Sistem Pendukung Keputusan Pemilihan Pemasok Bahan Baku Menggunakan Metode Technique for Order Preference by Similarity to Ideal Solution. Jurnal Integrasi Vol.8 No.1 hal. 56-60

[2] Dhining D., Rokhayati Y., Kurniawan, D.E., 2017 Penerapan Replikasi Data pada Aplikasi Ticketing Menggunakan Slony PostgreSQL. Journal of Applied Informatics and Computing (JAIC), Vol. 1 No.1 hal. 9-18.
[3] Kurniawan, D.E., Fajrianto, R., 2017. Sistem Pemantau Koneksi Internet Menggunakan Sistem Informasi Geografis dan SMS Gateway. Seminar Ilmiah Sistem Informasi dan Teknologi Informasi Jilid 5 Vol. 1

[4] Suwu, C.R., Sukarsa, I.M., Bayupati, I.P.A., 2016. Pengembangan Sistem HRM Terintegrasi dengan Pendekatan ERP. Jurnal Merpati Vol.4 No.3

[5] Akbar, R., Juliastrioza, Arici, Y.R., 2015. Penerapan Enterprise Resource Planning (ERP) untuk Sistem Informasi Pembelian, Persediaan, dan Penjualan Barang pada Toko Emi Grosir dan Eceran. Jurnal Teknosi Vol.1 No.1 Oktober 2015 Hal. 7-17

[6] Pratama, D., Witjaksono, W., Ambarsari, N., 2016. Penerapan Sistem Informasi Berbasis Enterprise Resource Planning Menggunakan SAP Modul Plant Maintenance di PT .LenIndustri. Jurnal Sisfo Vol. 06 No. 01 Hal. 37-50.

[7] Wicaksono, A., Mulyo, H.H., Riantono, I.E., 2015. Analisis Dampak Penerapan Sistem ERP Terhadap Kinerja Pengguna. Jurnal Binus Business Review (BBR) Vol. 6 No.1 Hal. 25-34.

[8] Zaidir, Ardani, A. 2017. Analisis dan Perancangan Sistem Informasi Terintegrasi untuk Manajemen Produksi, Persediaan dan Distribusi Barang (Studi Kasus: Pabrik Kemasan Kertas CV. Yogyakartas). Jurnal Teknologi Informasi Vol XII No. 35

[9] Dalimunthe, N., Mustofa, G. 2016. Analisis Penerimaan Pelanggan Terhadap Sistem Informasi Website PLN dengan Model T AM. Seminar Nasional Sistem Informasi Indonesia, 1 November 2016

[10]Sayekti,F., Putarta, P., 2016. Penerapan Technology Acceptance Model (T AM) dalam Pengujian Model Penerimaan Sistem Informasi Keuangan Daerah. Jurnal Manajemen Teori dan Terapan Tahun 9. No.3

[11] Supriyati, 2017. Aplikasi Technology Acceptance Model Pada Sistem Informasi Manajemen Rumah Sakit. Jurnal Bisnis \& Manajemen Vol.17 No.1 Hal. 81-102 